\title{
Determination of geometrical parameters of the diamond gear hones for the finishing of gears
}

\author{
M. G. Storchak' ${ }^{1}$ Yu. M. Danylchenko ${ }^{2}$ \\ 1 - Institute for Machine Tools University of Stuttgart, Germany; \\ 2 - Igor Sikorsky Kyiv Polytechnic Institute, Kyiv, Ukraine
}

Received: 02 September 2019 / Accepted: 18 September 2019

\begin{abstract}
The formation of the service properties of the gears occurs at the stages of their finishing using processes such as gear grinding, shaving, gear honing, lapping, etc. The main task of the synthesis of technological systems for the gears finishing processing is to determine the optimal parameters and structure of the technological system that provide the specified properties of gears. One of the first stages of the synthesis of technological systems for the gears finishing processing is the determination of the tool geometric parameters. To determine these parameters, a complex of software-implemented algorithms for their calculation has been developed. Using the example of rolling gear tools such as diamond gear hones, an analysis of the influence the independent characteristics of machine engagement on the area of the tool geometric parameters existence is carry out. Based on this analysis, a model of the tool geometry machine engagement with the machining gear was developed. This model is an integral part of the synthesis of technological systems for the gears finishing processing. As a result of this model functioning, the geometric parameters and optimal shapes of the diamond gear hones working layer have been synthesized.
\end{abstract}

Keywords: Gear, technological system, synthesis, geometrical parameters.

\section{Introduction}

The contact conditions between a tool and a workpiece in such a complex movement as it occurs in the finishing of gears are mainly established by the law of motion, the form, the position in space and the geometrical dimensions of the working areas in contact [1], [2]. The form and the geometrical dimensions of a workpiece are clearly defined and, in most cases, cannot be changed in the design phase of a technological system for the finishing of gears. These parameters can only be changed for a tool. Hence, when constructing an information system for the finishing of gears, it is the first and one of the main stages to develop a model that imitates the geometry of machine engagement and can establish the form and the geometrical dimensions of the tool's working part.

One of the fundamental demands on the model imitating the geometry of machine engagement is to establish the set of possible values for the parameters of the tool during its total life. It is obvious that this is useful for rack tools only in a narrow range of parameter variation between two dressing processes and a change in the tooth thickness of the gear to be cut during the machining, since all parameters of machine engagement remain unchanged outside this range.

The model of the machine engagement geometry to be developed is an idealized model as the apparatus of gear theory, developed for precise connections, is used for its description. Hence, the field of application for this model is defined by the accuracy of the tool, the machined gears, the demands on the model and the accuracy of the calculation methods used. If it is necessary to calculate the geometrical parameters of high-precision tools, e.g. for the machining of high-precision measuring gears, the model has to be supplemented by taking account of the errors in form, the position of the tool-gear pair in space, calculation errors, etc. In addition, it must be taken into consideration that the model imitating the geometry of machine engagement is an element (object) of the information system. The model can, however, be used independently, for example, in order to synthesize the optimum forms of the tool's working part and to calculate the geometrical parameters of its working part. In addition, the development of the imitation model makes it possible to numerically model the machine engagement in every interval. In this way, the information quantity increases considerably.

\section{Model of the machine engagement geometry}

The geometrical parameters of machine engagement are calculated based on a calculation method that is independent of the reference generating profile [3]. The modifications of the method are related to disk rolling tools [1],

M. G. Storchak

michael.storchak@ifw.uni-stuttgart.de
Yu. M. Danylchenko

yumd@i.ua 
[4], [5], [6]. These methods make it possible to establish the entire existence range of the tool-gear contact with varying parameters, when the tool is worn down and the material of the allowance is removed.

Fig. 1 shows the general flow chart of the model developed for the geometry of machine engagement for the finishing of gears.

The first step when establishing the parameters of machine engagement geometry is to prepare the input data. There are two possibilities to do this: $a$ ) the input data are determined according to the drawing of the gears or $b$ ) the input data are realized by deciphering the real gear pair or one gear of the pair. In the first case, difficulties may arise only if some necessary data are missing. This is actually linked to missing geometrical parameters of the mating gear. If these parameters are missing, this causes uncertainty in the search for coordinates of the starting point in the active area on the tooth profile of the gear to be cut, which is particularly important for finishing processes. In the second case, an algorithm has to be developed to decipher the geometrical parameters of a gear or a gear pair to be cut. Serving as a basis for such an algorithm is the well-known system for deciphering gear drives [7], [9]. Fig. 2 depicts a flow diagram of the software-implemented algorithm developed for deciphering the geometrical parameters of gears. The central task of this algorithm is to establish the contact ratio of the gear pair $\mathrm{P}_{b t}$, for which the value is assumed to be the most plausible standard tabular value. Three cases are possible when establishing $\mathrm{P}_{b t}: a$ ) the contact ratio is determined by direct measurement; $b$ ) by measuring the tooth distance, and $c$ ) the contact ratio cannot be measured directly, e.g. if the gears are worn down considerably. In the latter case, the contact ratio is established by solving a system of two equations which are formulated by measuring the distance between spheres on two different cylinders or by measuring the tooth thickness on two different cylinders with any diameter at all.

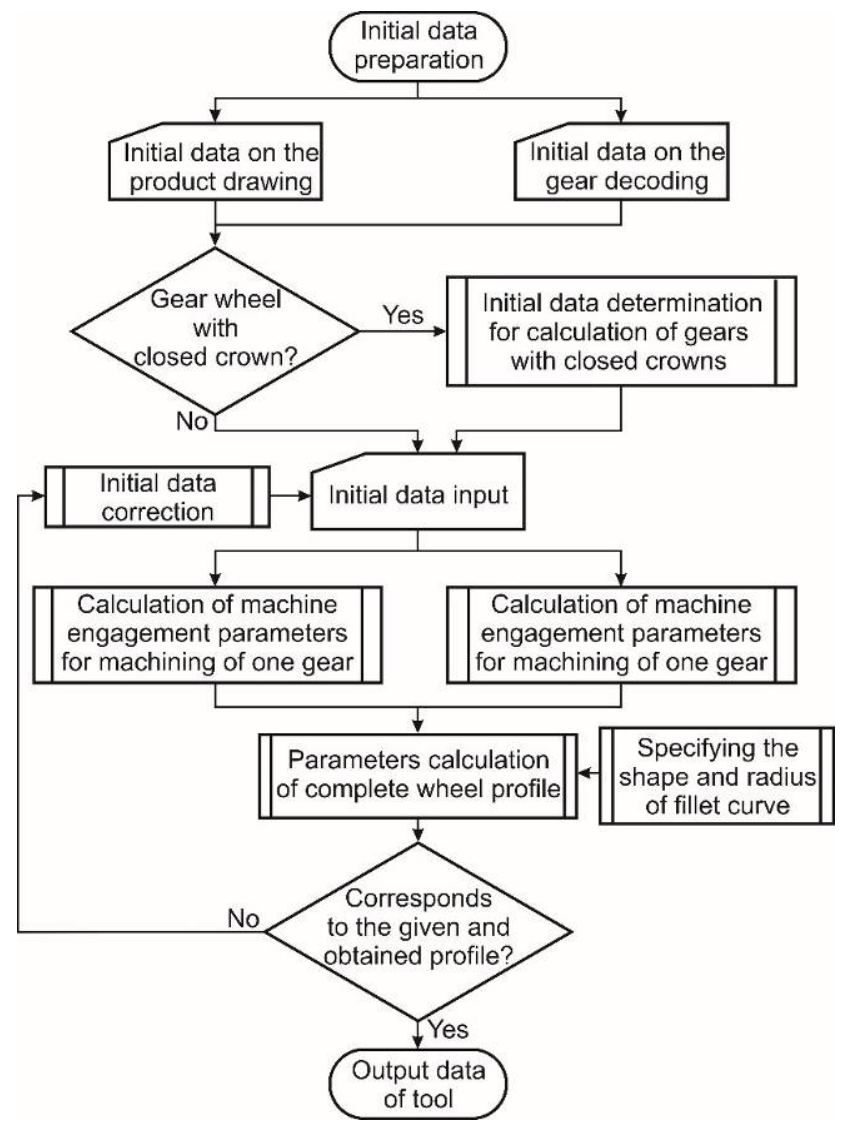

Fig. 1. Flow diagram with respect to the developed model algorithm of the machine engagement geometry for gear finishing

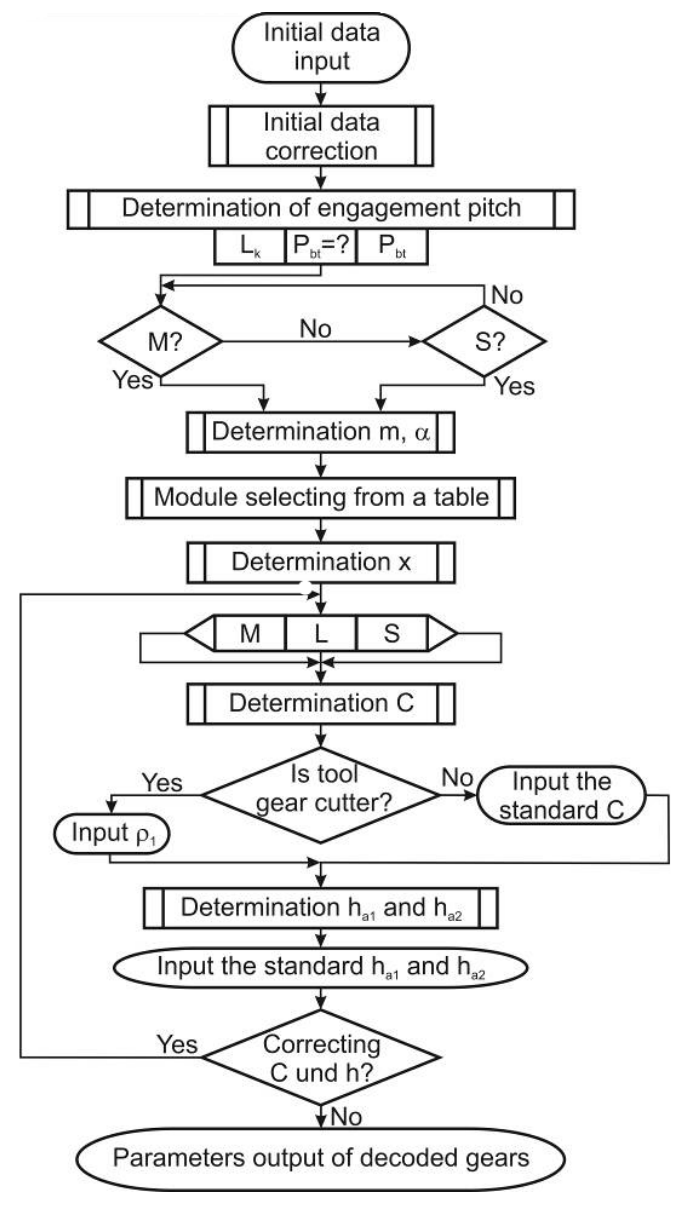

Fig. 2. Flow diagram of the algorithm for decoding geometrical parameters of gears

In the next step, it must to be checked whether the gear has a closed rim (e.g. cluster gears, gears with extensions, etc.). If the gear rim is open, the input data are entered directly. If the gear has a closed rim, the optimum crossing angle of the tool axes $\Sigma$ and the gear to be cut have to be established before entering the input data, since the only machining process for such products is the machining with disk tools (e.g. gear honing, gear shaving, gear lapping, etc.). In this case, the extension prevents the tool from coming out so that it is necessary to reduce the angle $\Sigma$. At the same time, the productivity of the machining process is directly in proportion to the angle $\Sigma$. Hence, the greatest possible value of the 
angle $\Sigma$ must be used. In order to establish the limiting values of $\Sigma$, it is necessary to analyse the mutual arrangement of the disk tool and the machined gear with the closed rim - Fig. 3.

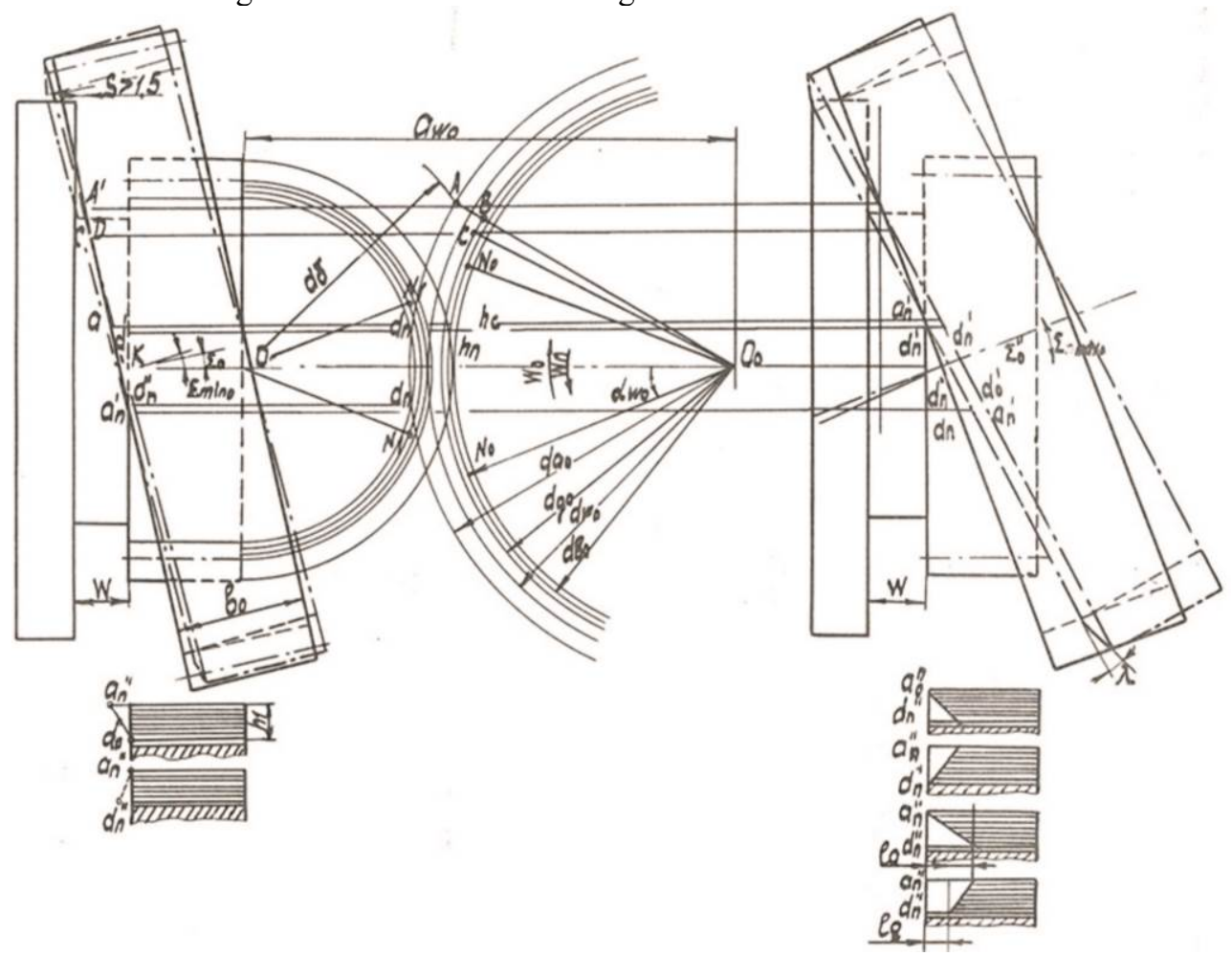

Fig. 3. Scheme of the relative position of the disk tool and the machined gear with the closed rim

The angle $\Sigma$ can reach its maximum value by engaging the surface of the tool's tooth tips with the surface of the gear's extension with a diameter $d_{\sigma}$ - point $K$. Thus the coordinates of point $K$ are to be established. The radius vector of point $K$ in the moving coordinate system $X_{1} O_{1} Y_{1} Z_{1}$ is defined as follows:

$$
r_{1}=M_{1} \cdot r
$$

where $r$ is the radius vector of point $K$ in the unmoving coordinate system $X_{1} O_{1} Y_{1} Z_{1} ; M_{1}$ is the transition matrix from a fixed to a moving coordinate system.

Since the point $K$ is in the periphery of the extension, it follows that $z=0$ and thus the matrix $M_{1}$ has the following form:

$$
\left|\begin{array}{ccc}
1 & 0 & -a \\
0 & \cos \Sigma & W \cdot \sin \Sigma \\
0 & \sin \Sigma & -W \cdot \cos \Sigma \\
0 & 0 & 1
\end{array}\right|
$$

By representing Equation (1) in a Cartesian equation, replacing the values $x, y, z$ with its expressions in parametrical form and performing the transformations, the desired equation is obtained to establish the greatest possible angle $\Sigma$ in an implicit form:

$$
\arcsin \left[\frac{\sqrt{d_{\sigma}^{2} \cdot \operatorname{tg}^{2} \Sigma-4 \cdot W^{2}}-2 \cdot a_{W 0} \cdot \operatorname{tg} \Sigma}{d_{a 0} \cdot \operatorname{tg} \Sigma}\right]-\arccos \left[\frac{2 \cdot W \cdot \cos \Sigma+2 \cdot W \cdot \sin \Sigma \cdot \operatorname{tg} \Sigma}{d_{a 0} \cdot \operatorname{tg} \Sigma}\right] .
$$

Regarding the angle $\Sigma$, Equation (3) is solved by means of a program-based algorithm using the halving division. After the input data have been entered, the geometrical parameters of the tool-gear machine engagement are actually calculated. Two options are possible in this case: $a$ ) the calculation is carried out for the machining of a gear and $b$ ) the calculation is carried out for the machining of a group of gears. These calculations are based on a method that presents the existence range of machine engagement as a function of independent parameters, establishing the length and the position of the line of engagement in space as well as the size and the position of the active part in the line of engagement [1], [6]. Clearly describing this function are the following independent parameters: the engagement angle 
between the tool and the gear to be cut $-\alpha_{n w 01}$, the inclination angle of the tooth trace (or the crossing angle of the axes -

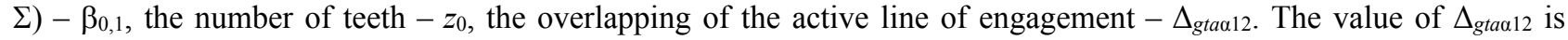
assumed to be 0 when calculating the geometrical parameters of a grinding tool 's machine engagement, as the greatest area of machine engagement [1] and the overlapping of the active line of engagement are guaranteed due to the stiffness of the tool's working elements. The area of machine engagement is established taking account of the following limitations: the form of the gear surface, the technological possibilities of tool production and its application to existing machine tools, the strength of the tool teeth as well as the technical and economic machining parameters. When analyzing the functions which describe the area of the tool-gear engagement, it was found that the area is defined by the variation range of the angle $\alpha_{n w 01}$ [1], namely by its upper and lower limits. According to the principle of establishing these boundaries, a calculation algorithm is developed depending on the assumed system of boundary conditions and the calculation of intermediate values. The system of transcendental equations describing the functions of independent parameters is solved with halving division. The upper and lower limits of the existence area of machine engagement are defined under the block of boundary conditions. The block contains the following limitations: a limitation of the diameter of the tooth tip circle $-d^{*}{ }_{a 0}$, the value of the radial play between the tooth tips of the gear to be cut and the tooth space of the tool $-C^{*}{ }_{01}$, the tooth thickness of the gear to be cut on the diameter of the tooth tip $S^{*}$ na0, the diameter of the involutes' limiting points $-d^{*}{ }_{10}$ and the limitation of the tooth space width on the diameter of the involute's limiting points $S^{*}{ }_{1 n 0}$.

The value "eps" defines how precise the existence limits of machine engagement can be established. The branching of the algorithm for establishing the upper and lower limits is given by a fixed value $B$, which takes on the values 0 or 1 , depending on the branch for which the calculation was carried out. For any fixed value of $\alpha_{\text {nw01 }}$, the area of the normal tool working layer and its volume can be calculated with the following equation:

$$
S=\int_{0}^{\frac{d_{a 0(1)}-d_{10(1)}}{2}} S_{n x 0}(h) d h+\int_{0}^{\frac{d_{10(1)}-d_{10(n)}}{2}} S_{n l 0}(h) d h-\int_{0}^{\frac{d_{a 0(1)}-d_{a 0(n)}}{2}} S_{n a 0}(h) d h-\int_{0}^{\frac{d_{a 0(n)}-d_{10(n)}}{2}} S_{n x 0}(h) d h,
$$

where:

$$
S_{n x 0}=\left(d_{a 0(1)}-h\right) \cdot\left(\frac{S_{t a 0(1)}}{d_{a 0(1)}}+i n v\left(\alpha_{t a 0(1)}\right)-i n v\left(\arccos \left(\frac{d_{b 0}}{d_{a 0(1)}-h}\right)\right)\right) \cdot \cos \left(\operatorname{arctg}\left(\frac{\left(d_{a 0(1)}-h\right) \cdot \operatorname{tg} \beta_{a 0(1)}}{d_{a 0(1)}}\right)\right) .
$$

Regarding a hypothetical pair of a tool and a group of gears, the geometry of machine engagement is calculated based on the fact that the area of machine engagement is established for every gear of the group. In addition, it is also checked where the starting point of the active tooth profile is located for every gear of the group within the possible overlapping of the active line of engagement - Fig. 4.

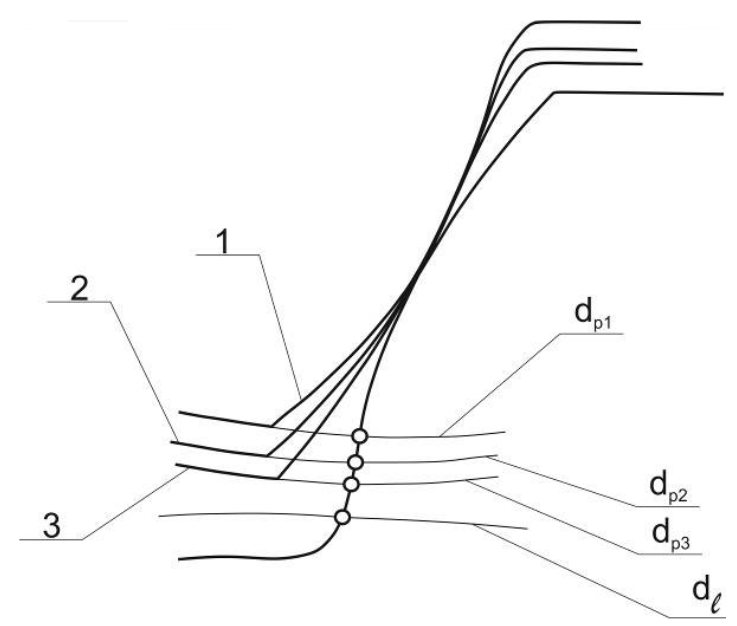

Fig. 4. The location of the starting point of the active tooth profile for every gear of the group

The existence area of a machine engagement was established for a group of gears by finding the intersection of the sets of areas for every gear of the group. In this case $z_{0}, \beta_{0}, S_{b n 0}, d_{\mathrm{a} 0}$, and $d_{10}$ were used as parameters for comparing these sets. If $\mathbb{E}$ is the set of all existence areas of machine engagement and $\mathbb{A} 1, \mathbb{A} 2, \ldots$ An (where $n$ is the number of the machined gears of the group) are the subsets of the machine engagement's existence area that belong to the set $\mathbb{E}$ and 
are limited by the existence condition of their areas, then the necessary condition for the existence of a common area is that there is a non-empty set [8], [12] of intersections of all subsets of $\mathbb{A}$ :

$$
\bigcap_{k=1}^{n} \mathbb{A}_{k} \subset \mathbb{E}=\mathbb{B} \neq \varnothing
$$

where $\mathbb{B}$ is the subset of the machine engagement's existence area for the group of gears; $\varnothing$ is the empty set.

The subset $\mathbb{B}$ can be empty (for a group of gears, there is no common area of machine engagement) or can also show interruptions (for a particular part of the whole group, there are particular areas of machine engagement). Fig. 5 shows, for example, the possible variants for the existence of $\mathbb{B}$ for a group of four gears. In order to be able to definitely select the existence range of the tool-gear machine engagement for a group of gear drives, the following sufficient conditions must be met:

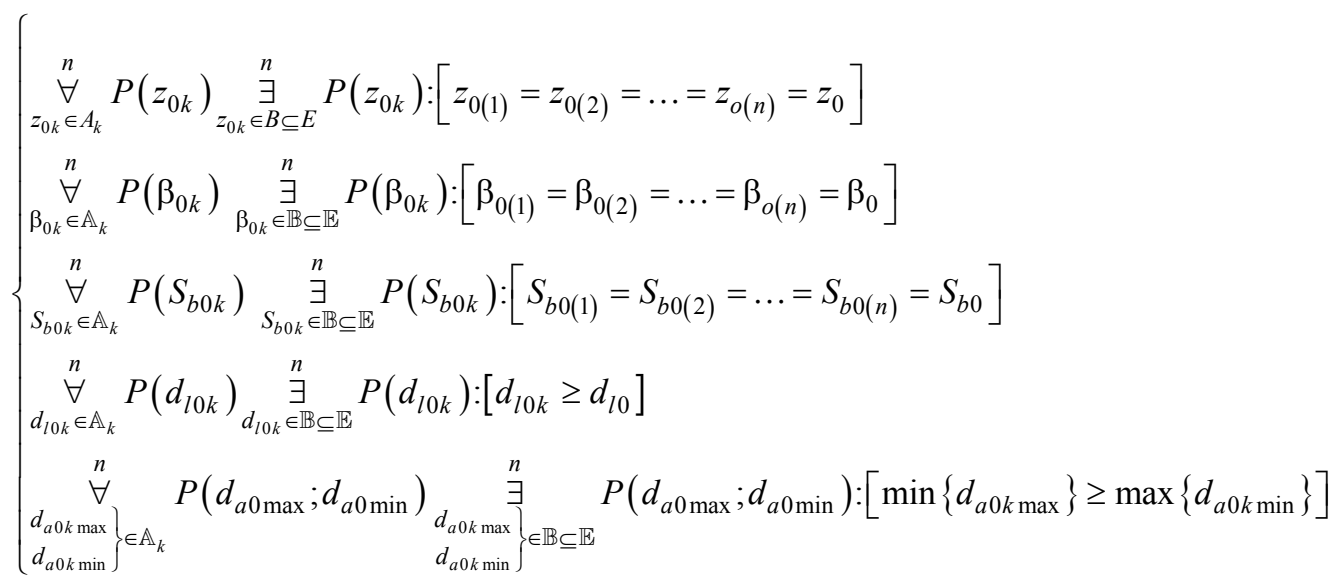

For every value of $\alpha_{\mathrm{nw} 01}$, it has to be checked whether the sufficient conditions (6) are met. The calculation algorithm is a set of blocks that are intended for examining the necessary conditions (5) followed by the sufficient conditions (6) for the existence of a tool-gear machine engagement. The algorithm has a direct hierarchical structure. Calculating the existence range of the tool-gear machine engagement results in the determination of the geometrical tool parameters. As a further step in the course of the algorithm, the total profile parameters of the gear to be cut are calculated. This includes establishing the surface of the root as well as its connecting curve, the working part of the tooth profile and the surface of the tooth tips. The main problem here is to define the coordinates of the connecting curve. The connecting curve is an envelope of the family surfaces linking the corners of the generating contour with their working parts [10], [11].

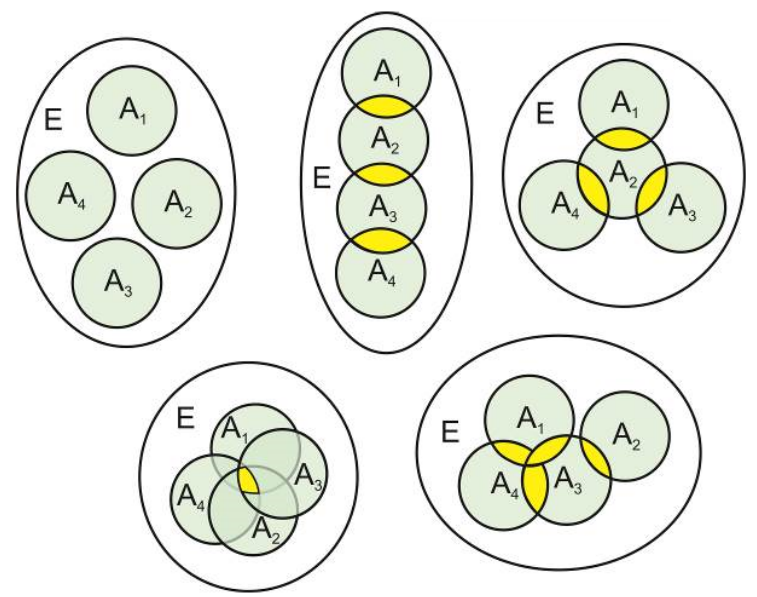

Fig. 5. Possible options for the existence of a submultiplicity $\mathbb{B}$ for a group of four gears

If the gear is made with a rack tool, then the connecting curve has the form of a longish involute. Yet, if the gear is made with a helical tool, then the connecting curve has the form of an extended epicycloid. The coordinates of the connecting curve and the other part of the machined gear's tooth profile are calculated by solving the equation for the engagement of a tool in the known form and dimensions with the gear to be cut [7], [10]. Fig. 6 shows the flow chart of the algorithm developed for calculating the desired tooth profile. 
According to the algorithm, the tooth profile is defined as the resulting intersection of the curves which are formed by different parts of the generating tool surface. The tooth profile consists of the following parts:

- a root circle;

- a connecting curve which is formed by a part of the generating contour, linking its main or modified profile with the tip circle;

- a modification involute formed by a modified part of the generating contour;

- a main involute formed with the main profile of the generating contour;

- a tip circle.

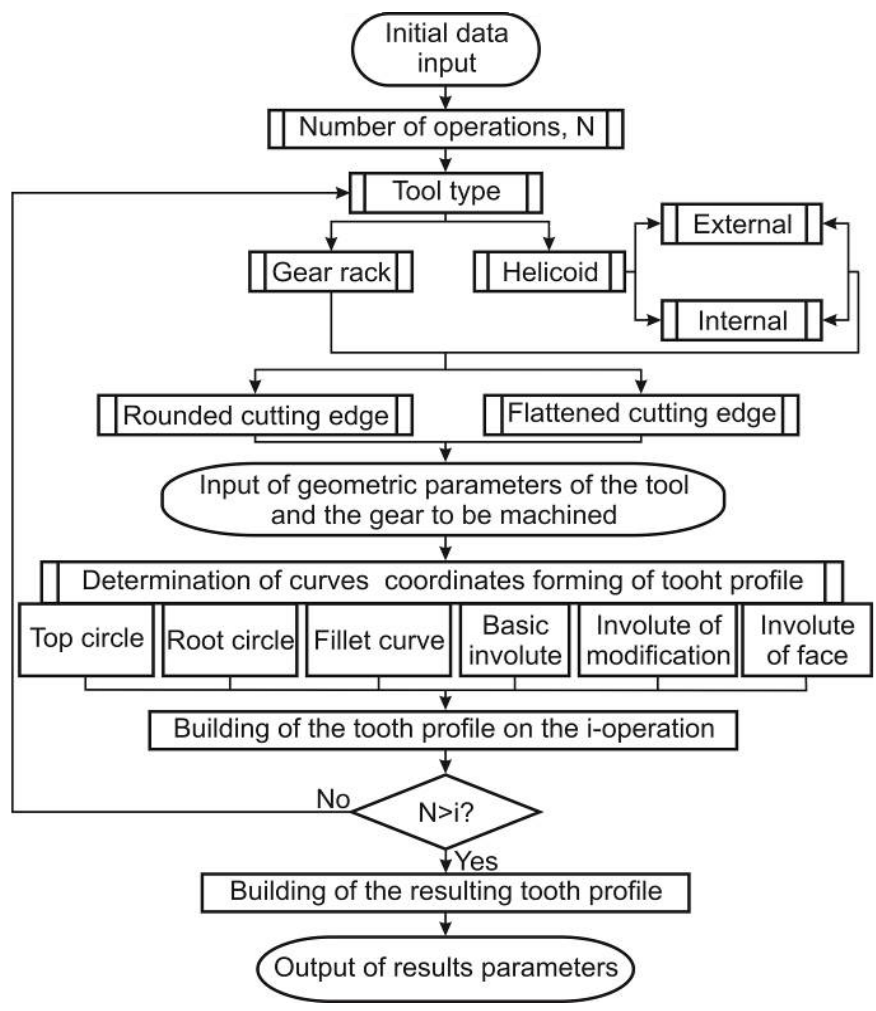

Fig. 6. Flow diagram of the algorithm for calculating the geometrical parameters of the complete gear tooth profile

Depending on the form of the connecting part of a generating contour, the connecting curve is composed of one curve (if the connecting part is a rounded edge) or three curves (if the connecting part is a blunt edge with a chamfer). The coordinates of the connecting curve are calculated in the face plane of the gear to be cut according to the following equation system [7], [10], [11]:

$$
\begin{gathered}
\left\{\begin{array}{l}
x=r \cdot \sin \delta \\
y=r \cdot \cos \delta
\end{array}\right. \\
r=0.5 \cdot d_{w} \cdot \frac{\cos \alpha_{t w 01}}{\cos \alpha_{y}} ; \delta=\alpha_{t w 01}-\alpha_{y}-\varphi_{y},
\end{gathered}
$$

where $\mathrm{r}$ is the radius vector of the generating point; $\delta$ is the angle of the curve; $\alpha y$ is the curve's pressure angle at the generating point; $\varphi_{y}$ is the angle between the $Y$ - axis and the limiting position for the radius vector of the neighboring curve's starting point.

The coordinates of the curves' intersections are established by jointly solving the approximated equations of the curves obtained according to Equation (7). The resulting profile of the gear to be cut is compared with the given profile according to the form and the radius of the connecting curves. The radius of curvature of the connecting curve is determined from the known dependences [10], [11]:

$$
\alpha=\frac{\left[1+\left(\frac{d y}{d x}\right)^{2}\right]^{\frac{3}{2}}}{\frac{d^{2} y}{d x^{2}}}
$$


If there are considerable differences between these parameters, the tool parameters and the parameters of machine engagement are corrected. The profiles are calculated repeatedly until the specified parameters are obtained.

\section{Objective functions of the model}

To select the optimization system from the information system, objective functions have to be established according to the synthesis method proposed [1]. The objective functions are defined resulting from the functioning of the models developed. With regard to the model imitating the geometry of machine engagement, objective functions (broadly speaking - model characteristics) are functions describing how the parameters of machine engagement affect the modification of the machined gear's tooth profile. Among these parameters are those which the designer can vary in the elaboration of finishing processes, namely parameters of the tool and its relative arrangement to the machined gear. That is why the independent parameters in the model worked out here are used as the parameters of machine engagement, clearly describing the spatial arrangement of the tool's line of engagement with the gear and the arrangement on the line of its active part. For identifying this characteristic, it is necessary to analyse the change in the geometrical characteristic of the tool when varying independent parameters of machine engagement. It was found that the change in the geometrical properties of the tool and the variation range of $\alpha_{n w 01}$ in the machine engagement's input parameters depend mainly on the parameters of the gear to be cut and its connected gears as well as on the variation range in the independent parameters of machine engagement and the limiting parameters - Fig. 7 and Fig. 8.

The character of these dependences shows the polyvalence of the desired functions. They can differ significantly from a monotonous (curves 1, Fig. 7 and Fig. 8) up to an extreme character (curves 2, Fig. 8), depending on the arrangement of the input and limiting parameters. The limiting parameters, such as $C_{01}^{*}, S_{n a 0}^{*}, e_{1 a 0}^{*}, d_{a 0}^{*}$, considerably influence the character of these functions. These parameters basically determine the existence range of machine engagement. The maximum existence range is determined by the limiting parameters $C_{01}^{*}, d_{01}^{*}, S_{n a 0}^{*}, e_{1 a 0}^{*}, d_{a 0}^{*}$. The lower limit is mostly determined by the limiting parameter $d_{01}^{*}$, i.e. by the absence of interference. In rare cases, the lower limit is determined by the limiting parameters $C_{01}^{*}, S_{n a 0}^{*}$ though.
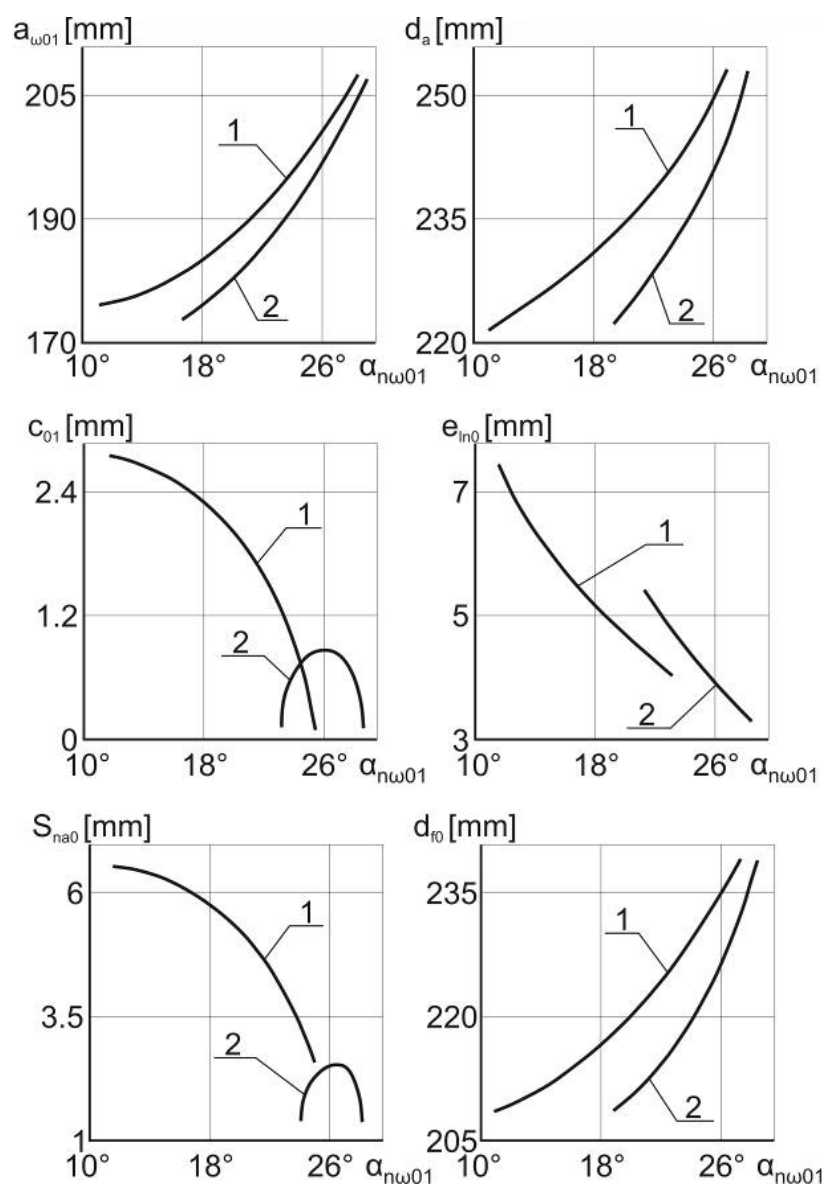

Fig. 7. Dependence of the tool's geometrical characteristics on the initial parameters of machine engagement 
Analogous dependences of the machine engagement for the pair of tool/group of gears have a similarly complex and polyvalent character. It is more practical to take the thickness of the tool teeth on the diameter of the involutes" end point $S_{1 n 0}$ as an independent variable for describing the geometry of machine engagement for the pair of tool/group of gears. Sometimes the thickness of the tool teeth on the base circle diameter $S_{b 0}$ is taken as variable. The selection of this variable can be explained by the fact that the thickness of the tool teeth $S_{1 n 0}$ or $S_{b 0}$ is a general value for the machine engagement of the pair of tool/group of gears. In addition, the tool has its own angle of engagement $\alpha_{\text {nw01 }}$ for the gearing with each gear of the group.

Fig. 9 presents the dependences resulting from changes in some geometrical parameters of machine engagement $\alpha_{n w 01}, S_{n a 0}, d_{a 0}$, when machining a group of four gears for $\mathrm{m}_{0}=3.5 \mathrm{~mm}$ and $\mathrm{m}_{0}=5 \mathrm{~mm}$. For the same value of $\mathrm{S}_{1 n 0}$, the tool has the greatest and smallest possible values of geometrical parameters within the value of $\Delta_{\text {gtaa 12 }}$. The hatched areas define the set of geometrical tool parameters when machining a group of gears. The curves $S_{a 0 \max }, S_{a 0 \text { min }}$, $d_{a 0 \max }, d_{a 0 \min }$ and $d_{a 0 \min }$ meet the given limitations and the variation range of $\Delta_{\text {gtaa12 }}$. When analyzing how the normal working layer area of the tool (4) depends on the parameters of machine engagement, especially on $z_{0}$ and $\beta_{0}$, it is particularly noticeable how complex and polyvalent the properties of machine engagement are. The character of this dependence is influenced significantly by the limitation of the machine engagement's existence range.

The existence range of machine engagement allows to establish a set of geometrical tool parameters with which the finishing of different gear profiles can be carried out. Resulting from the functioning of the model developed for the geometry of machine engagement, the tool parameters can be definitely chosen only by checking the agreement of the input gear profile with the machined profile. The algorithm developed for calculating the coordinates of the gear profile allows the desired agreement. The tooth profile of the gear to be cut varies significantly, depending on the form of the edge that links the working area of the tool with the surface of the tooth tips. This is mainly the case in the area of the connecting curve. Fig. 10 depicts a tooth profile machined with a rack and a helicoid or helical tool. During the finishing process the tooth profile of the machined gear changes its form, particularly after several processes and mainly in the area of the connecting curve.

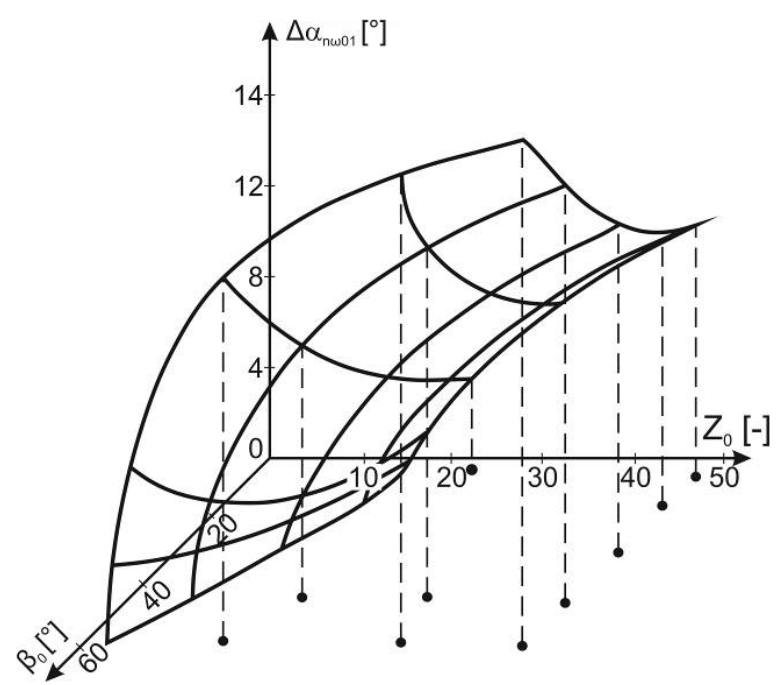

Fig. 8. Dependence of the machine's pressure angle on the tool's geometrical parameters
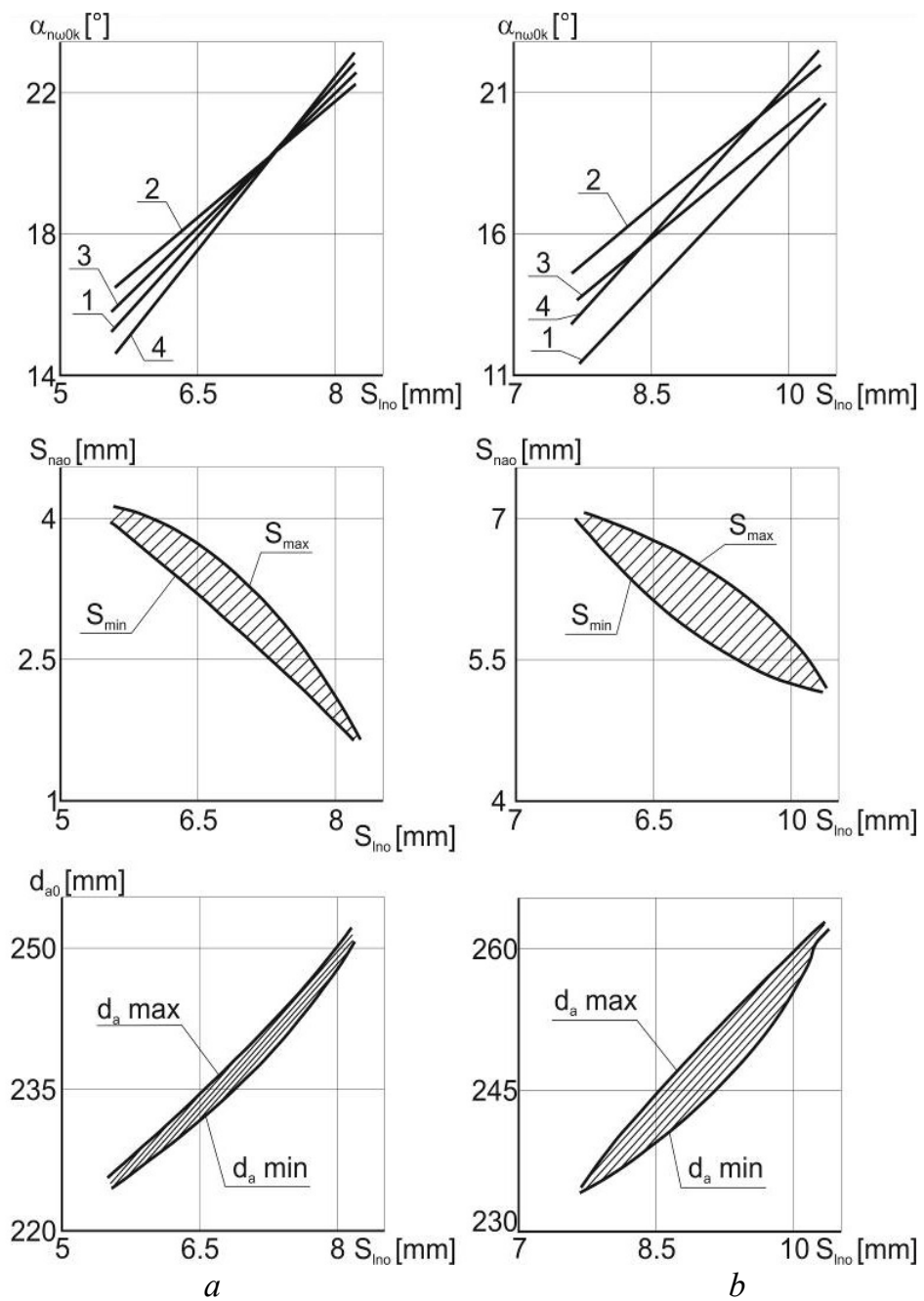

Fig. 9. Change in the geometrical parameters of machine engagement when finishing a group of four gears $\left(a-\mathrm{m}_{0}=3.5 \mathrm{~mm}, b-\mathrm{m}_{0}=5 \mathrm{~mm}\right)$ 

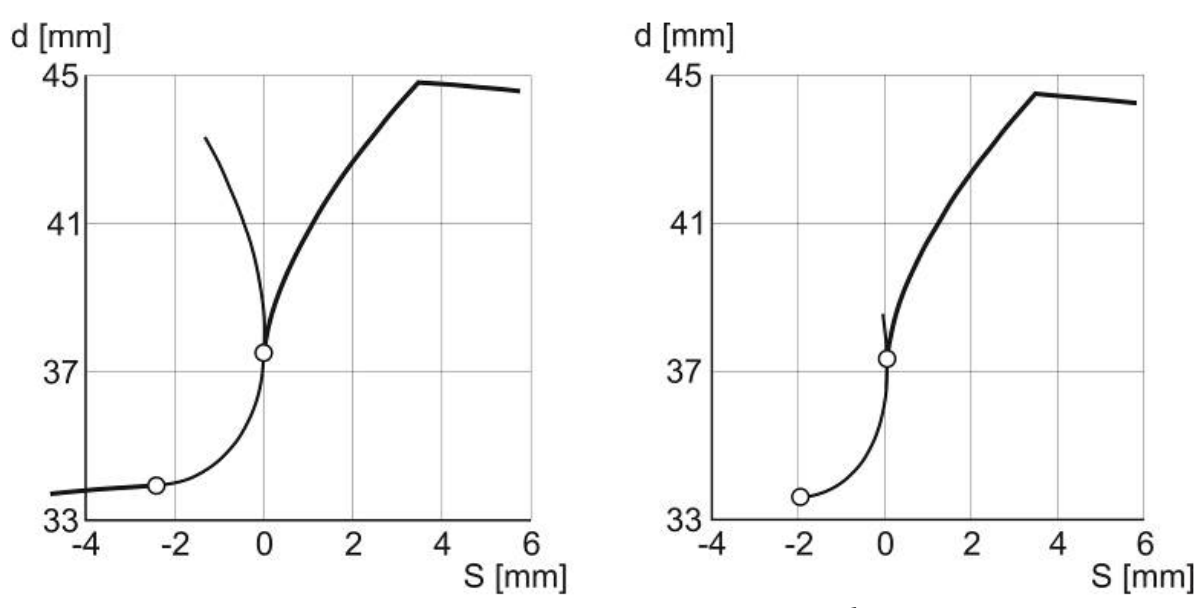

$a$

$b$

Fig. 10. The gear tooth profile machined with a rack $(a)$ and helicoid $(b)$ tool

Fig. 11 shows the tooth profile after two finishing processes: gear grinding with the method of the Neils company (tool - rack) and gear honing (tool - involute helicoid). In the area of the connecting curve, a step can be seen that was formed in the last machining operation. This step is often the reason for greater noises and vibrations of the gear drive due to the fact that the contact profiles of the connected gears overlap. Of course, the existence, the size and the location of this step is definitely determined by the set of machine engagement parameters in the finishing of the gear. In order to avoid these overlapping or interferences, gear profiles with modifications (spiral point) are used for the finishing of critical gears that are formed with the help of special production profiles.

The design of tools with such a profile is

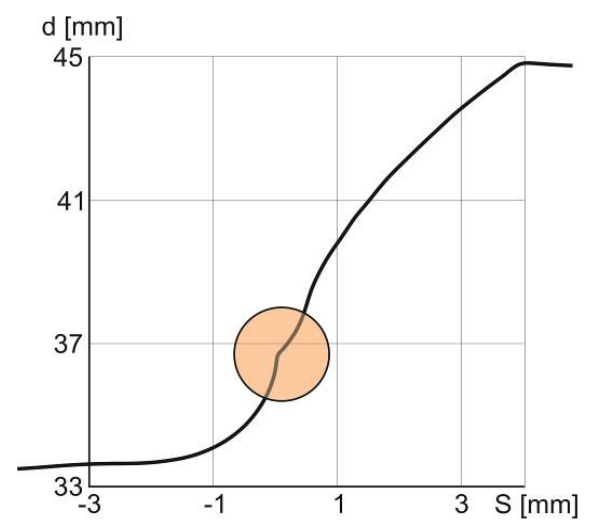

Fig. 11. Tooth profile after tooth grinding with the method of "Niels-Simmons" and gear honing

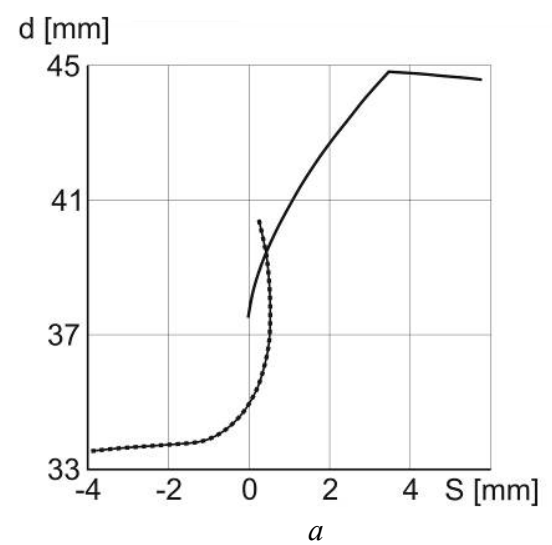
challenging, as the involute of the modification and the involute of the gear profile have no real intersections very often. This leads to the formation of a step near the limiting point of the involute and thus to the occurrence of the interference mentioned above. Fig. 12 shows examples of modified gear profiles with and without a step in the area of the tooth profile's limiting point. It is apparent from Fig. 12 that the relative position of the main involute, the involute of the modification and the connecting curve as well as their components can be definitely controlled by changing the parameters of machine engagement. For such a specific control, numerical values are, however, required characterizing the tooth profile of the gear, particularly of its connecting curve. Such an integral quantity is the curvature radius of the connecting curve [10], [11], which is established with the dependence (8).

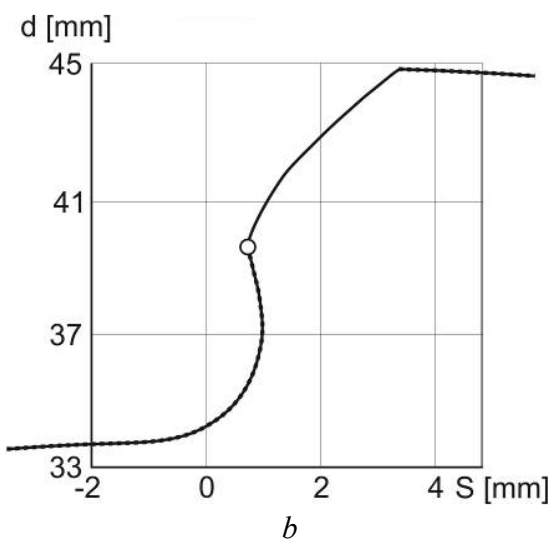

Fig. 12. Modified tooth profile with $(a)$ and without a step $(b)$ 


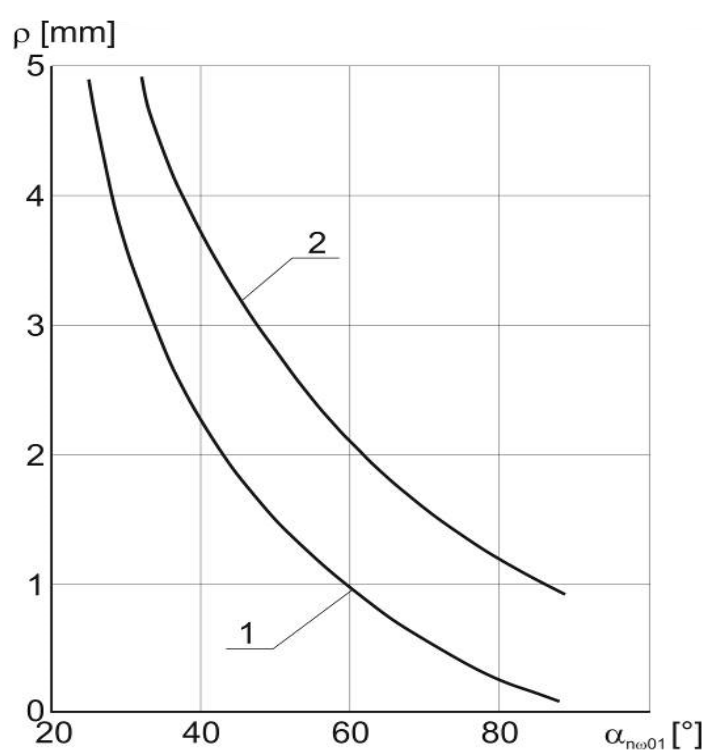

Fig. 13. The curvature radius of the connecting curve depending on the angle of engagement
Fig. 13 shows the curvature radius of the connecting curve depending on the magnitude of the actual angle of engagement $\alpha_{n w 01}$. As can be seen from Fig. 13, the curvature radius of the connecting curve changes significantly (in the examples here, it varies between 0.2 and $5.5 \mathrm{~mm}$ ). To assess the curvature of the connecting curve, some researchers

introduced various concepts - the arithmetic mean of the curvature radius, the mean integral radius, the apothem, the specific radius, etc. This approach produced only an estimation of the connecting curve's curvature. The algorithm developed makes it possible to establish the curvature radius of the connecting curve for the tooth profile of the gear at each point depending on the parameters of machine engagement as well as to compare it with the given curvature and the form of the connecting curve.

This offers the possibility for solving the inverse problem, i.e. establishing the parameters of the generating contour in accordance with a given form and curvature of the connecting curve, which is realized by a multiple iterative method for the solution of a direct problem. The analysis showed that the characteristics of the model (objective functions) depend on design parameters in a complex and polyvalent way. In this connection, it is difficult and impractical to explicitly choose the objective functions desired. Hence, the objective functions in the development of technological systems should be used as results of the functioning of the model simulating the geometry of machine engagement.

\section{Synthesis of the working layer forms of tools}

The functioning of the model developed for the geometry of machine engagement provides the optimum geometrical parameters of the tool and its position in space relative to the machined gear. The model should contribute as an integral part to the system of choosing the structure and the parameters of a technological system. In a few cases it can, however, be used as independent unit. One of the most practical results when using the model separately is the synthesis of the working layer forms of tools, namely their determination and optimization. Calculating the geometrical tool parameters in the existence range of machine engagement allows to establish the design dimensions of the tool's working part at any point in time (for every tool condition). In this way it is possible to identify the form and the dimensions of the completely worn working layer of the tool - Fig. 14.

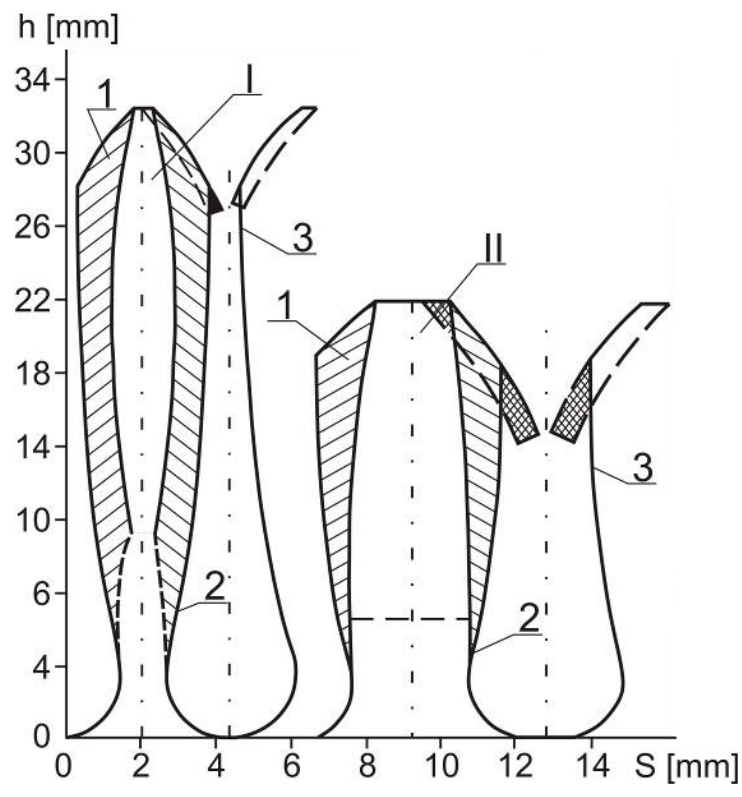

Fig. 14. The shape and dimensions of the fully worn tool working layer 
The figure shows the optimum and the conventional form of disk tools' working layer. A comparison of their forms and areas indicates that applying the developed model makes it possible to establish the geometrical dimensions and the position of the tool's working layer, which has a much greater area than before. Of course, the tool life, especially of diamond tools, is in proportion to the volume and also to the area of the working layer's normal section in this case. Hence, those forms in Fig. 14 are preferred most of which the working layer is one or more orders of magnitude greater compared to conventionally used forms. The production of a tool with such a working layer is technologically difficult though. Apart from that, the entire existence range of the tool parameters cannot be realized due to the limitations of the equipment used, the regrinding or finish grinding of tools, the technological characteristics of its production, etc. On the other hand, the need for increasing the tool life leads to the desire to raise the volume of the tool working layer. These two contradictory endeavours create the necessity to solve the following optimization problem:

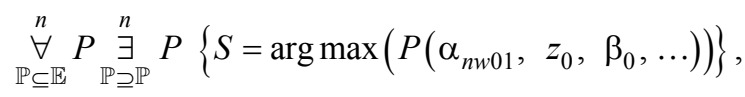

where $\mathbb{E}$ is the parameter set of machine engagement, $\mathbb{P}$ is the subset of tool parameters and its arrangement relative to the gear to be cut.

The surface of the function $S$ is multimodal with deep gradients. This can be noticed when analysing the surface $S$ as a function of the two arguments $z_{0}$ and $\beta_{0}$. Based on topological singularities of the surface $S$, it is most practical to use nullmethods for solving Equation (9) in order to find an absolute extremum of a function with several variables, i.e. methods in which the partial derivatives of the desired function do not have to be calculated. Analysing known methods showed that the method of the deformed polyhedron (Nelder-Mead method) [8] is the most reasonable one in this case, because it is very flexible and can take local topological properties of the surface into account. The extremum of thefunction $\mathrm{S}$ was established using the standard algorithm of the deformed polyhedron method. The solution of Equation (9) together with the boundary conditions described above made it possible to synthesize the optimum forms of the working layer for disk rolling tools - Fig. 15.

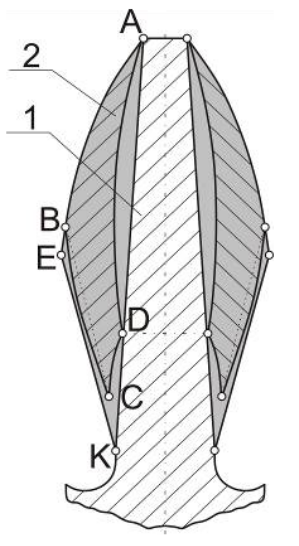

$a$
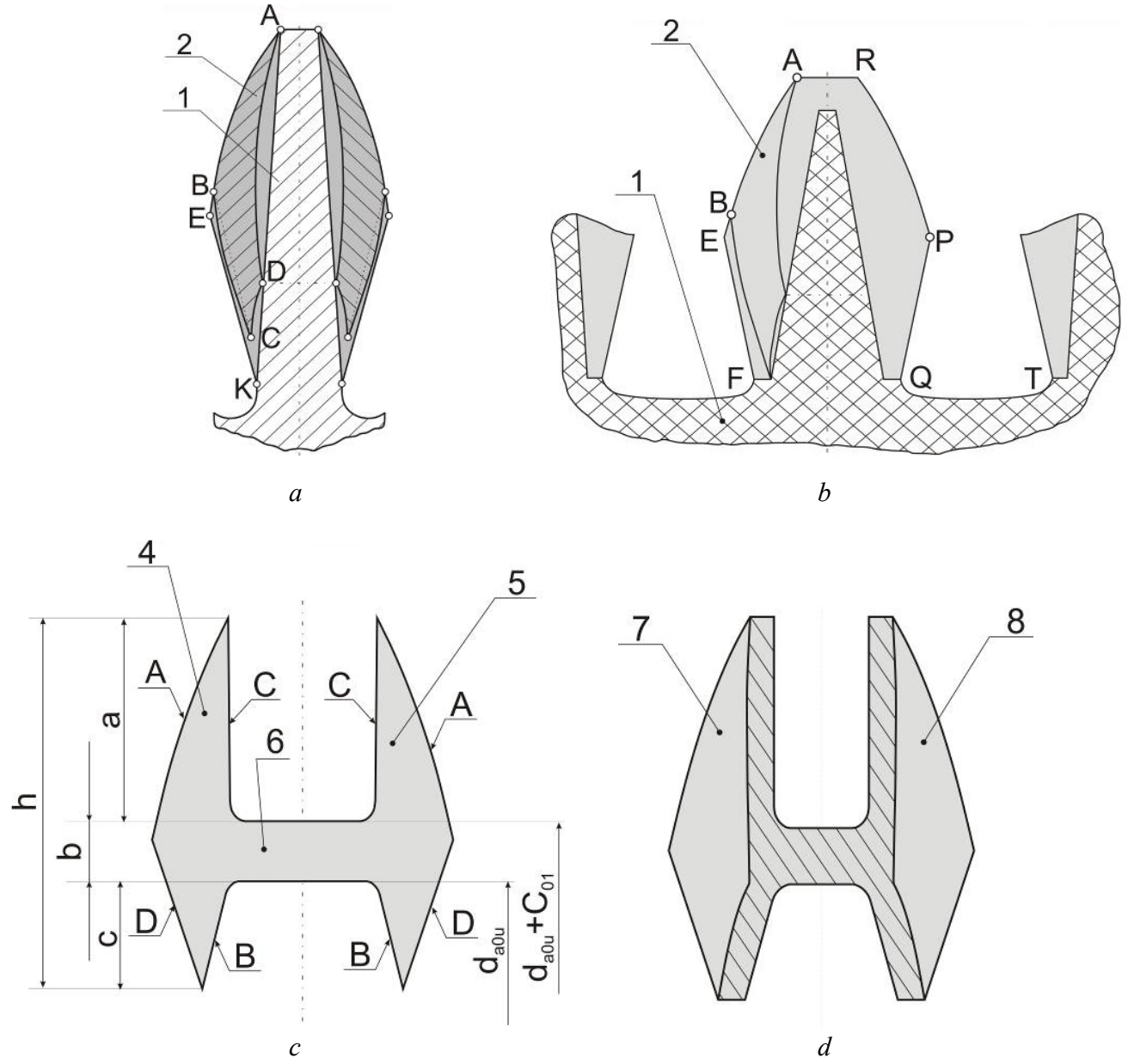

8

Fig. 15. Synthesized optimal forms of the working layer of disk tools 


\title{
Conclusion
}

Using the developed software-implemented algorithms for calculating the geometric parameters of rolling tools for finishing machining gears, an analysis of influence of the characteristics of machine gearing on the existence area of the geometry of machine gearing of the tool with the wheel is carry out. Based on the analysis, a geometry model for machine engagement has been developed. Using this model, geometrical parameters and optimal shapes of the working layer of diamond gear hones of diamond gear hones were synthesized.

\section{References}

1. Сторчак М. Г. Синтез технологических систем для отделочной обработки зубчатых колес: дис. доктора технических наук: 05.02.08. - Киев: ИСМ им. В.Н. Бакуля, 1994. - 448 с.

2. Radzevich, S. P.: Theory of Gearing. Kinetics: Geometry and Synthesis. 2nd edition, Taylor \& Francis Group, 2018,898 p.

3. Вулгаков Э. Б. Теория эвольвентных зубчатых передач. - М. : Машиностроение, 1995. - 320 c.

4. Bouzakis, K.-D.; Lili, E.; Michailidis, N.; Friderikos, O.: Manufacturing of cylindrical gears by generating cutting processes: A critical synthesis of analysis methods. CIRP Annals - Manufacturing Technology, 2008, Vol. 57, Issue 1, pp. 676 - 696.

5. Bergs, T.: Cutting force model for gear honing. CIRP Annals - Manufacturing Technology, 2018, Vol. 67, Issue 1, pp. 53 56.

6. Krivosheya A., Danilchenko J., Storchak M., Pasternak S. Design of Shaping Machine and Tooling Systems for Gear Manufacturing. In: Theory and Practice of Gearing and Transmissions. Mechanisms and Machine Science, vol 34, Springer, 2016, pp. $425-450$.

7. Болотовский И. А. Справочник по геометрическому расчету эвольвентных зубчатых и червячных передач. - М.: Машиностроение, 1986. - 448 с.

8. Kreyszig, E.: Advanced Engineering Mathematics. John Wiley\&Sons, 10-th Edition, 2011, 1283 p.

9. Курлов, Б. А. Расшифровка цилиндрических и конических зубчатых передач. - М.: Машиностроение, $1972 .-134$ с.

10. Litvin, F. L.; Fuentes, A. Gear Geometry and Applied Theory. Second Ed., Cambridge University Press, Cambridge, 2004, $800 \mathrm{p}$.

11. Babichev, D.; Storchak, M.: Synthesis of cylindrical gears with optimum rolling fatigue strength. Production Engineering, Research and Development, 2015, Vol. 9, Issue 1, pp. 87 - 97.

12. Moore, J.: Introduction to Abstract Algebra. Academic Press, 2014, 291 p.

\section{Визначення геометричних параметрів алмазних зубчастих хонів для опоряджувальної обробки зубчастих колес}

\author{
М. Г. Сторчак, Ю. М. Данильченко
}

Анотація. Формування експлуатаційних властивостей зубчастих коліс відбувається на етапі опоряджувальної обробки $з$ використанням таких прочесів як зубошліфування, зубошевінгування, зубохонінгування, притирання, прироблення, тощо. Головним завданням синтезу технологічних систем опоряджувальної обробки зубчастих коліс є визначення оптимальних параметрів та структури технологічної системи, яка забезпечує задані властивості зубчастих коліс. Одним з перших етапів синтезу технологічних систем для опоряджувальної обробки зубчастих коліс є визначення геометричних параметрів інструменту. 3 метою визначення ции параметрів розроблено комплекс програмно-реалізованих алгоритмів їх розрахунку. На прикладі обкатних зубооброблювальних інструментів, таких як алмазні зубчасті хони, здійснено аналіз впливу незалежних характеристик верстатного зачеплення на зону існування геометричних параметрів інструменту. На базі иього аналізу розроблена модель геометрії верстатного зачеплення інструмента з оброблювальним колесом, яка $\epsilon$ складовою частиною синтезу технологічних систем для опоряджувальної обробки зубчастих коліс. За допомогою иієї моделі синтезовані геометричні параметри та оптимальні форми робочого шару алмазних зубчастих хонів.

Ключові слова: Зубчасті колеса, технологічна система, синтез, геометричні параметри інструменту.

\section{Определение геометрических параметров алмазных зубчатых хонов для отделочной обработки зубчатых колес}

\author{
М. Г. Сторчак, Ю. М. Данильченко
}

Аннотация. Формирование эксплуатационных свойств зубчатых колес происходит на этапах их отделочной обработки с применением таких процессов как зубошлифование, зубочевингование, зубохонингование, притирка, приработка и т. $n$. Основной задачей синтеза технологических систем отделочной обработки зубчатых колес является определение оптимальных параметров и структуры технологической системы, обеспечивающих заданные свойства зубчатых колес. Одним из первых этапов синтеза технологических систем для отделочной обработки зубчатых колес является определение геометрических параметров инструмента. Для определения этих параметров разработан комплекс программно-реализованных алгоритмов их расчета. На примере обкатных зубообрабатываюших инструментов, таких как 
алмазные зубчатые хоны, выполнен анализ влияния независимых характеристик станочного зацепления на область существования геометрических параметров инструмента. На основе этого анализа разработана модель геометрии станочного зачепления инструмента с обрабатываемым колесом, которая является составной частью синтеза технологических систем для отделочной обработки зубчатых колес. С помощью этой модели синтезировань геометрические параметры и оптимальные формы рабочего слоя алмазных зубчатых хонов.

Ключевые слова: Зубчатые колеса, технологическая система, синтез, геометрические параметры инструмента.

\section{References}

1. Storchak, M. (1994), Tekhnologicheskiye sistemy dlya otdelki zubchatykh koles [Technological Systems for Finishing Gears], Institute for Superhard Materials, Kiev, Ukraine.

2. Radzevich, S.P. (2018), Teoriya zatsepleniya. Kinetika: geometriya i sintez [Theory of Gearing. Kinetics: Geometry and Synthesis], 2nd ed., Taylor \& Francis Group, Florida, USA.

3. Vulgakov, E.B. (1995), Teoriya evol'ventnogo zatsepleniya [Theory of involute gearing], Mashinostroyeniye, Moscow, Russia.

4. Bouzakis, K.-D., Lili, E., Michailidis, N. and Friderikos, O. (2008), "Manufacturing of cylindrical gears by generating cutting processes: A critical synthesis of analysis methods", CIRP Annals-Manufacturing Technology, vol. 57, no. 2, pp. 676 - 696.

5. Bergs, T. (2018), "Cutting force model for gear honing, CIRP Annals-Manufacturing Technology, vol. 67, no. 1, pp. 53 - 56.

6. Krivosheya, A., Danylchenko, Ju., Storchak, M. and Pasternak, S. (2016), "Design of Shaping Machine and Tooling Systems for Gear Manufacturing", In: Theory and Practice of Gearing and Transmissions, Springer, pp. 425 - 450.

7. Bolotovskiy, I.A. and dr. (1986), Spravochnik po geometricheskomu raschetu evol'ventnykh $i$ chervyachnykh peredach [Handbook of geometric calculation of involute and worm gears], Mashinostroyeniye, Moscow, Russia.

8. Kreyszig, E. (2011), Rozshyrena inzhenerna matematyka [Advanced Engineering Mathematics], John Wiley\&Sons, 10-th Edition, Newark, USA.

9. Kurlov, B.A. (1972), Rasshifrovka tsilindricheskikh i konicheskikh zubchatykh koles [Decoding of cylindrical and bevel gears], Mashinostroyeniye, Moscow, Russia.

10. Litvin, F.L. and Fuentes, A. (2004), Heometriya peredach ta prykladna teoriya [Gear Geometry and Applied Theory], 2 nd edn., Cambridge University Press, Cartagena, Spain, https://doi.org/10.1017/CBO9780511547126

11. Babichev, D. and Storchak, M. (2015), "Synthesis of cylindrical gears with optimum rolling fatigue strength", Production Engineering, Research and Development, vol. 9, no. 1, pp. $87-97$. 